\title{
Factors associated with the presence of helminth eggs in the soil of public areas in Concepción, Chile
}

\author{
Fatores associados à presença de ovos de helmintos no solo de áreas públicas \\ em Concepción, Chile
}

\author{
Susana Castro-Seriche"; Ítalo Fernández²; Carlos Landaeta-Aqueveque ${ }^{1 *}$ (1) \\ ${ }^{1}$ Facultad de Ciencias Veterinarias, Universidad de Concepción, Chillán, Chile \\ ${ }^{2}$ Facultad de Ciencias Biológicas, Universidad de Concepción, Concepción, Chile
}

How to cite: Castro-Seriche S, Fernández I, Landaeta-Aqueveque C. Factors associated with the presence of helminth eggs in the soil of public areas in Concepción, Chile. Braz J Vet Parasitol 2020; 29(3): e003120. https://doi.org/10.1590/S1984-29612020054

\begin{abstract}
The aim of this study was to assess the association between the distance to the nearest feces, the type of substrate to be studied (feces, soil, grass), and whether a given area was licensed or not with the presence of helminth eggs in Concepción, Chile. A total of 256 samples taken from feces and either from soil or grass at $10 \mathrm{~cm}, 50 \mathrm{~cm}$, and $100 \mathrm{~cm}$ from feces (including 16 public areas), were examined for the presence of parasites using the $\mathrm{ZnSO}_{4}$ technique. The association between variables with the presence of eggs was assessed with multifactorial logistic regressions. $24.21 \%$ of samples presented at least one egg. The higher odds of Toxocara egg presence was positively associated with the licensed 'area type' and the soil 'sample type' (when compared with feces). The odds of Ancylostomatidae egg presence was positively associated with the licensed 'area type', but negatively associated with the soil 'sample type' (compared with feces). The results suggest that finding eggs must be interpreted differently based on the parasite species and substrate to be analyzed, and that the presence of parasitized dogs is a more important contributing factor than the frequency with which the ground is cleaned of feces.
\end{abstract}

Keywords: Ancylostomatidae, public areas, soil contamination, soilborne disease, Toxocara, zoonosis.

\begin{abstract}
Resumo
O objetivo deste estudo foi avaliar a associação da distância das fezes mais próximas, o tipo de substrato a ser estudado (fezes, solo, grama) e se as áreas foram licenciadas ou não, com a presença de ovos de helmintos zoonóticos em Concepción, Chile. Um total de 256 amostras colhidas no fecais, no solo ou na grama e a 10,50 e $100 \mathrm{~cm}$ de fezes (incluindo 16 áreas públicas), foram examinadas quanto à presença de parasitas usando a técnica de flotação de sulfato de zinco. A associação de variáveis com a presença de ovos foi avaliada com regressões logísticas multifatoriais. Os $24,21 \%$ das amostras apresentaram pelo menos um ovo. As chances mais altas de ovos de Toxocara foram associadas positivamente ao 'tipo de área' licenciado e ao 'tipo de amostra' do solo (em comparação com as fezes). As chances de ovos de Ancylostomatidae também foram positivamente associadas ao 'tipo de área' licenciado, mas negativamente associadas ao 'tipo de amostra' do solo (em comparação com as fezes). Os resultados sugerem que o achado de ovos deve ser interpretado de maneira diferente em relação às espécies de parasitas e ao substrato a ser analisado, e que a presença de cães parasitados parece ser mais importante do que a frequência de limpeza das fezes do solo.
\end{abstract}

Palavras-chave: Ancylostomatidae, áreas públicas, contaminação do solo, doenças transmitidas pelo solo, Toxocara, zoonose. 


\section{Introduction}

Several studies have assessed the global risk of zoonotic soilborne parasites originating from dog feces. Some have focused on domestic environments, either considering dogs visiting a veterinary clinic (Ferreira et al., 2016; Tamponi et al., 2017) or analyzing the presence of parasites in dog feces within the domicile (Acosta-Jamett et al., 2014; Quilodrán-González et al., 2018). Others have analyzed the presence of zoonotic parasites in public areas (Sprenger et al., 2014; Medina-Pinto et al., 2018; White et al., 2019), where many have reported parasite findings of high diversity or frequency (Sprenger et al., 2014; Ferreira et al., 2016); still, others have reported not finding any parasites at all (Melín-Coloma et al., 2016). Interpreting the level of risk in these studies is not easy to accomplish given the differences in the design and laboratory techniques used, which can yield different results (Collender et al., 2015). In studies of parasites in public environments, some differences are easily visible in terms of study design; for example, some studies focus on the presence of parasites in feces in public areas (Medina-Pinto et al., 2018; Utaaker et al., 2018), while others focus on the presence of parasites in the ground (Sprenger et al., 2014; Melín-Coloma et al., 2016). Thus, it is not easy to determine whether the design of the study contributes to these differences in results, nor is it possible to elucidate how these differences translate into different risk levels of human infection.

One important factor to consider in the study of parasites in public areas is the representativity of the areas sampled. For example, most studies have focused on licensed public areas, which are gardened and frequently cleaned (Sprenger et al., 2014; Melín-Coloma et al., 2016). In addition, some studies have focused on taking soil samples at a distance from feces, suggesting that the close presence of feces could affect the results (Sprenger et al., 2014; Melín-Coloma et al., 2016). The type of ground surface is another factor that can affect the finding of parasites; for instance, some studies have focused on sand (Sprenger et al., 2014), others have focused on and compared both soil and grass, and others have analyzed soil thickness (lannacone et al., 2012). These variables can affect the overall findings and the interpretation of the risk of infection. Thus, in the present investigation, we assessed the different factors affecting the recovery of parasite eggs from public areas.

To achieve this aim, we selected the city of Concepción, Chile for this study. Concepción is located in the coastal plain (the flatland between the La Costa mountain range and the Pacific Ocean) of the Biobío region and features a transitional climate that falls somewhere between the classifications of warm Mediterranean (Csb, after Köpen classification) and wet temperate oceanic ( $\mathrm{Cfb}$ ), and lies within the limits between Central and Southern Chile $\left(36^{\circ} 49^{\prime} 37^{\prime \prime} \mathrm{S} ; 73^{\circ} 3^{\prime} 1^{\prime \prime} \mathrm{W}\right)$. The size of free-roaming dog population was estimated to be 3,976 individuals in 2014 (Cerda P., 2014, unpublished data). In a nearby locality, Cabrero, four helminth taxa were found to be parasitizing dogs, Toxocara canis, Trichuris vulpis, Ancylostomatidae and Taeniidae (Quilodrán-González et al., 2018). These four taxa are potentially zoonotic: T. canis is the etiological agent of the visceral, ocular and neurologic larva migrans, Ancylostomatidae species cause cutaneous larva migrans, Taeniidae species cause several diseases, with the cystic echinococcosis as the most detrimental and Trichuris vulpis causes an intestinal helminthiasis (Giudice et al., 2019; Mohd-Shaharuddin et al., 2019; Reyes et al., 2019; Rostami et al., 2019). The zoonotic potential of T. vulpis can be controversial (Traversa, 2011), however the molecular identification of T. vulpis in humans and the molecular identification of Trichuris trichiura in dogs, in addition of the need of molecular analysis for an adequate identification (Mohd-Shaharuddin et al., 2019) suggest that those Trichuris eggs found in Cabrero (which could also belong to T. trichiura), could be, at least potentially, zoonotic. These four parasitic taxa found in dogs of Cabrero use eggs shed with the feces as the transmission way. Thus, the presence of these eggs in the environment not only is expected, but also, it means a risk of infection for humans, in addition to dogs, and, given the short distance between Cabrero and Concepción $(72 \mathrm{Km})$, the presence of these parasite species in Concepción is expected. This is also supported by the canine population size, previously mentioned, in addition to the existing climate, which may favor the presence of parasites of dogs in public areas (understanding that these areas include parks, squares, or public grounds of undetermined use). Hence, we aimed to assess the association between ground type (sand, soil, or grass), the distance to the nearest feces, and area type (licensed -i.e. a private company bided on its cleaning- or unlicensed -no one or only neighbors clean it) with the presence of parasites in the public areas of Conception.

\section{Materials and Methods}

The minimum sample size for estimating proportions was calculated with the binomial distribution following Vallejo et al. (2013), with 95\% confidence, 6.5\% of accepted error, and an unknown population size, which output a sample size of 224 samples. For a numerical convenience, a total of 256 samples obtained from public areas in Concepción city were examined for parasites. The design examined 32 fecal samples obtained from licensed areas 
and 32 from unlicensed areas (yielding a total of 64 fecal samples). In addition, four samples were taken from the ground by drawing a cross $10 \mathrm{~cm}$ away from the feces. These four samples were mixed in a single sample for each fecal sample (a total of $64,10 \mathrm{~cm}$ samples). The same procedure was repeated at $50 \mathrm{~cm}$ and $1 \mathrm{~m}$ from the feces (a total of $64,50 \mathrm{~cm}$ samples and a total of $64,1 \mathrm{~m}$ samples; Figure 1). Feces that were situated closer than $2 \mathrm{~m}$ to other feces were not included in the study. The number of samples obtained from soil or grass was not determined previously to ensure that this assignment was random. Feces surrounded by more than one type of ground within $1 \mathrm{~m}$ were not included to ensure that only one type of ground was included per fecal sample. The studied areas were selected at random within each type to avoid biasing the results. The licensed areas examined were Ecuador Park, Acevedo Square, La Cruz Square, Los Fresnos Park, Bicentenario Park, Universidad de Concepción, de Armas Square, and Condell Square. The unlicensed areas were Los Fresnos, La Cantera de Mauzhier, La Agüita de la Perdiz, Pedro de Valdivia Bajo, La Virgen Hill, Las Heras, Argentina Avenue, and Paicaví Avenue (Figure 2). The Unidad de Aseo y Ornato of the Municipalidad de Concepción provided information on which areas were licensed.

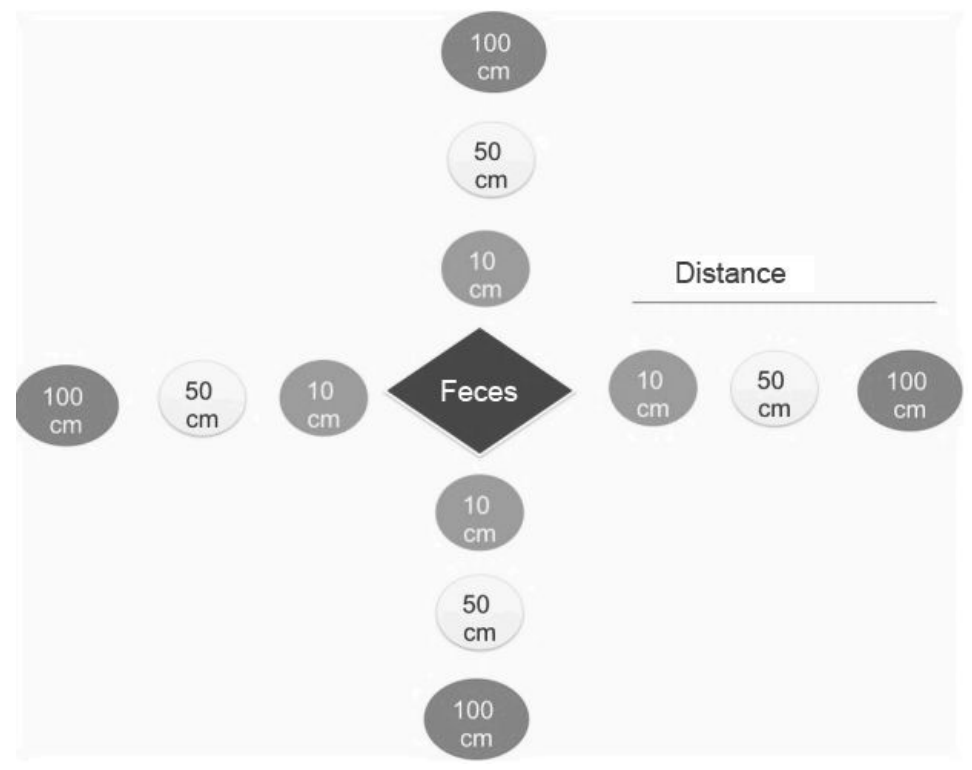

Figure 1. Scheme of the sample extraction performed for each fecal sample. Three samples were extracted at each of the four arms illustrated here. The four samples taken at the same distance were mixed as a sole sample.

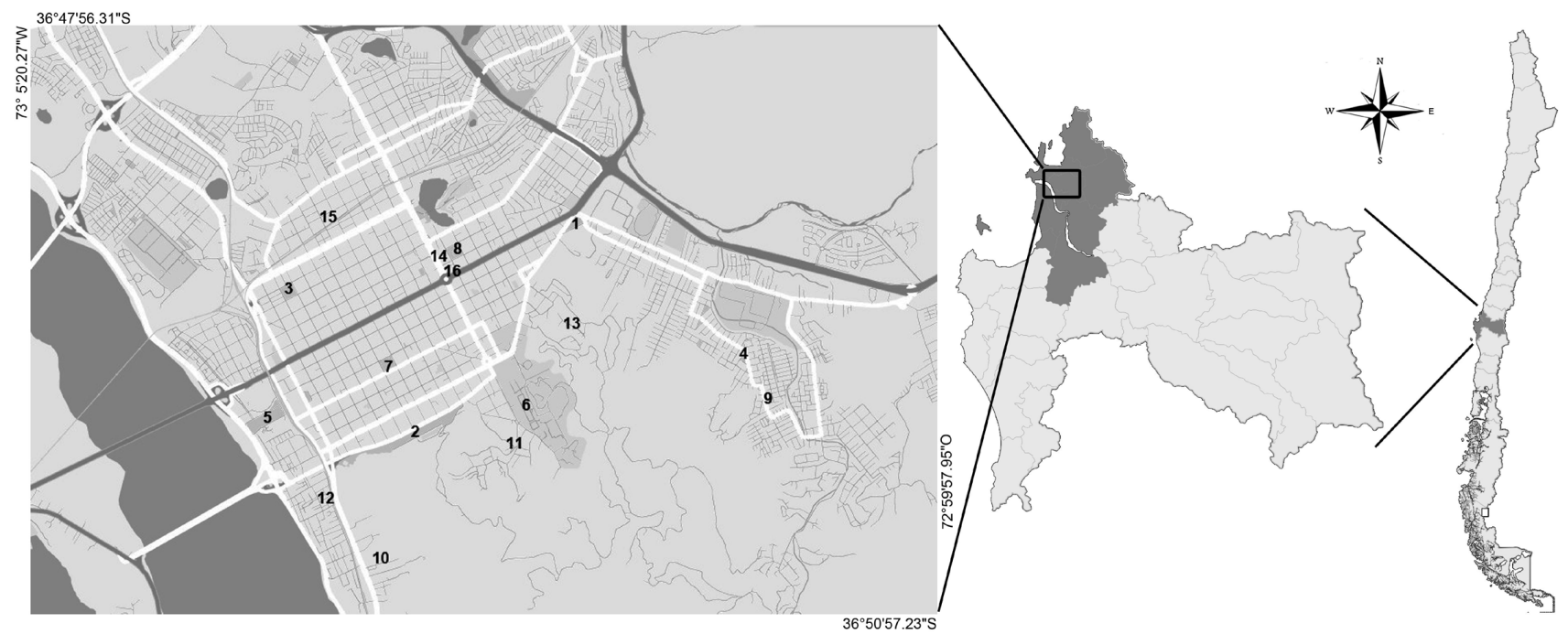

Figure 2. From right to left: map of Chile with the Biobío Region darkened, the Biobío Region with the Concepción Province darkened, Concepción City with the public areas identified with numbers. Areas examined for the presence of parasites. The licensed areas examined were, Acevedo Square (1), Ecuador Park (2), La Cruz Square (3), Los Fresnos Park (4), Bicentenario Park (5), Universidad de Concepción (6), de Armas Square (7), and Condell Square (8). The unlicensed areas were Los Fresnos (9), La Cantera de Mauzhier (10), La Agüita de la Perdiz (11), Pedro de Valdivia Bajo (12), La Virgen Hill (13), Las Heras (14), Argentina Avenue (15), and Paicaví Avenue (16). 
Sample collection was performed between November 2016 and May 2017. The sampling involved alternating between licensed and unlicensed areas in order to avoid temporal or climatic bias. For each fecal sample, the whole excrement was collected in a plastic bag. Ground samples $(5 \mathrm{~cm} \times 5 \mathrm{~cm})$ were taken to a depth of $5 \mathrm{~cm}$. Each ground sample was put into and mixed in a plastic bag. Both feces and ground samples were kept at $5^{\circ} \mathrm{C}$ until laboratory examination. The sampling was performed by only one person in order to avoid temporal and spatial bias.

\section{Laboratorial Analysis}

To determine the presence of parasites, $5 \mathrm{~g}$ of feces and $25 \mathrm{~g}$ of ground were diluted in $80 \mathrm{~mL}$ and $120 \mathrm{~mL}$ of zinc sulfate $(70 \% \mathrm{w} / \mathrm{v})$, respectively. Then, the solutions were sieved in a tea strainer with a simple gauze. After that, the liquid was sedimented and the supernatant was distributed in $15 \mathrm{~mL}$ centrifuge tubes and analyzed using the zinc sulfate flotation technique (Basso et al., 1998). In order to avoid bias, all laboratory procedures were performed by the same person.

\section{Epidemiological analysis}

Multi-factorial logistic regressions were used to assess the association between the sample type (feces, soil, or grass categories), the distance to the nearest feces (cm), and area type (licensed or unlicensed) with the presence of eggs. In the case of 'sample type', feces was the basal comparison category, and grass and soil were the dummy variables. Selecting the best model was accomplished by removing the variable with the highest $P$-value (i.e., that which was least significant) and comparing the likelihood between models. If there was a loss of likelihood when the variable was removed, the likelihood ratio test was used to check whether this loss was significant. If the loss of likelihood was not significant, the variable was removed. This procedure was repeated with the rest of the variables until the loss of likelihood was significant. In that case, the variable was not removed and this constituted the selected model. Two initial models were used for each parasite taxon: one including 'sample type' and 'area type' as the independent variables, and another including 'distance to the feces' (without considering 'distance to the feces' $=0$ ) and 'area type' as the independent variables. This consideration was taken given that 'distance to the feces' $=0$ means that 'sample type' $=$ feces; thus, the variables are not independent. The significance level was set at $P=0.05$. The $95 \%$ confidence intervals $(\mathrm{Cl})$ of the frequencies are given. All statistical procedures were performed using Stata 11/SE software (StataCorp Ltd., College Station, TX, USA).

All procedures were certified by the Comité de Bioética of the Facultad de Ciencias Veterinarias of the Universidad de Concepción, Chile (Certificate number CBE072017).

\section{Results}

In addition to the 64 fecal samples, 93 samples corresponded to grass ground and 99 to soil. Parasite eggs were found in 12 of the 16 examined public areas (75\%; Cl: 51.17-98.83). Considering all samples, 24.21\% (Cl: 18.9-29.5) presented at least one egg, and 8.59\% (Cl: 5.14\%-12.01\%), 16.02\% (Cl: 11.49\%-20.54\%), and 1.95\% (Cl: 0.25\%-3.66\%) of samples presented with Toxocara, Ancylostomatidae, and Trichuris eggs, respectively. Given the low frequency, Trichuris sp. eggs were not considered for statistical analysis.

Toxocara eggs were more frequently found in the soil than in grass and feces; Ancylostomatidae were less frequently found in soil. Conversely, both species were found more frequently in licensed areas than in unlicensed ones (Table 1).

The higher the odds with which Toxocara eggs were present was positively associated with the licensed 'area type' for both initial models, and also with soil as the 'sample type'. There was no association between the odds with which Toxocara eggs were present with grass as a 'sample type' (when compared with feces) (Table 1, LR1). There was no association between the odds with which Toxocara eggs were present with 'distance to the feces', hence, the output of this model is omitted.

Conversely, the odds with which Ancylostomatidae eggs were present was also positively associated with the licensed 'area type' after both initial models were tested; however, the odds were negatively associated with soil as a 'sample type' when compared with feces. There was no association between the odds with which Ancylostomatidae eggs were present with grass as a 'sample type' (Table 1, LR2). There was no association between the odds with which Ancylostomatidae eggs were present with the 'distance to feces', hence, the output of this model is omitted. 
Table 1. Parameters for the final logistic regressions (LR).

\begin{tabular}{|c|c|c|c|c|c|}
\hline $\begin{array}{l}\text { Variable [frequency } \% ; 95 \% \text { confidence } \\
\text { interval] }\end{array}$ & Odds ratio & $\begin{array}{l}\text { Standard } \\
\text { error }\end{array}$ & $\mathbf{z}$ & $\begin{array}{l}\text { Probability } \\
\text { value }\end{array}$ & $\begin{array}{c}95 \% \\
\text { Confidence } \\
\text { interval }\end{array}$ \\
\hline \multicolumn{6}{|c|}{ LR1 (Toxocara) } \\
\hline \multicolumn{6}{|l|}{ Area type (Unlicensed) [1.56; 0.6-3.73] } \\
\hline Licensed [15.63; 9.28-21.97] & 12.13 & 9.2 & 3.29 & $<0.01$ & $2.74-53.67$ \\
\hline \multicolumn{6}{|l|}{ Sample type (Feces)[3.13; 0-7.44] } \\
\hline Soil [15.15; 8.02-22.28] & 5.96 & 4.68 & 2.27 & 0.02 & $1.28-27.8$ \\
\hline \multirow[t]{2}{*}{ Grass $[5.38 ; 0.75-10]$} & 1.85 & 1.6 & 0.71 & 0.48 & $0.34-10.07$ \\
\hline & \multicolumn{3}{|c|}{ LR2 (Ancylostomatidae) } & & \\
\hline \multicolumn{6}{|l|}{ Area type (Unlicensed) [10.94; 5.48-16.39] } \\
\hline Licensed [21.09; 13.96-28.22] & 2.3 & 0.84 & 2.29 & 0.02 & $1.13-4.7$ \\
\hline \multicolumn{6}{|l|}{ Sample type (Feces)[23.44; 12.93-33.95] } \\
\hline Soil [7.07; 1.97-12.17] & 0.24 & 0.12 & -2.89 & $<0.01$ & $0.09-0.63$ \\
\hline Grass [20.43; 12.15-28.71] & 0.85 & 0.34 & -0.42 & 0.67 & $0.39-1.84$ \\
\hline
\end{tabular}

LR1: 'Toxocara Presence' = 'Area type' + 'Sample type', when the initial model included 'Area type' and 'Sample type' as factors; LR2: 'Ancylostomatidae Presence' = 'Area type' + 'Sample type', when the initial model included 'Area type' and 'Sample type' as factors. The basal level of each variable is given in parentheses; the parameter (odds ratio) is given for each dummy variable. $\mathrm{Z}$ is the value of the standardized normal distribution for the observed odds ratio.

\section{Discussion}

As expected, Ancylostomatidae showed the highest frequency, which is in agreement with the results of previous studies conducted in a nearby locality, Cabrero (Quilodrán-González et al., 2018). However, this study was not designed to estimate the frequency with which parasites occur in the samples, but rather to assess the factors affecting their presence; as such, comparisons with other studies are not necessarily very worthy.

The lack of an association between the presence of eggs with distance from feces suggests that feces mainly contaminate the soil that they make contact with; dissemination is thus of low importance or seemingly random regardless of the distance to the source feces.

The higher frequency with which Ancylostomatidae were present in feces when compared with soil is in agreement with the fact that this is not a very resistant egg; it easily dies in hot or dry conditions. In addition, if surviving, the larvae hatch soon in the environment, rendering it difficult to find eggs short after excretion (Bowman et al., 2011). Thus, if the finding of Ancylostomatidae eggs in soil is aimed, techniques that search for larvae - rather than for eggs - in that substrate could be more useful. Conversely, feces provide eggs with better protection, particularly given that eggs within feces are more protected from heat and solar radiation. Thus, the low protective conditions offered to eggs found in soil can reduce their frequency, and the likelihood of hatching before passing from feces to soil is in agreement with their lower frequency in the latter. This study was carried out mostly during the summer, which is rather hot and dry. New studies carried out during the winter (where the conditions are rather cold and rainy) are necessary to assess the presence of Ancylostomatidae eggs in soil in different climate conditions.

The higher resistance of Toxocara eggs allows them to accumulate over time in the environment, which can favor their frequency in soil; this is in agreement with the finding that these eggs were found in greater frequency in soil when compared with feces in this study. However, the same was expected for grass, but was not observed - at least not with statistical significance. Although it is difficult to propose a hypothetical cause underlying this phenomenon, some studies have suggested using different laboratory techniques to recover eggs in laboratory settings; it is thus possible that there are differences in the sensibility with which different techniques are used for each parasite group in each 'sample type' (Ruiz de Ybáñez et al., 2000; Zenner et al., 2002; Sievers et al., 2007; Collender et al., 2015). In this vein, it is possible that the technique used herein to recover eggs could not perform well when attempting to recover Toxocara eggs from grass. Another hypothesis is that feces in soil could be more easily stepped on 
than feces in grass, as people may walk more frequently over soil than grass. Thus, stepped-on feces found in soil could be more difficult to remove with the aid of cleaning services when compared with feces that are found in grass, enhancing the accumulation of eggs in soil. New studies are necessary to test these hypotheses in order to explain this difference.

Contrary to what was expected, eggs were more frequently found in licensed areas than in unlicensed ones. Although licensed areas are expected to be cleaned (and thus feces are expected to be more frequently removed here when compared with unlicensed areas), licensed areas attract more visitors, favoring the presence of dogs and their parasites. In addition, licensed areas are regularly watered, favoring the persistence of the parasites, as humidity is increased and temperatures are controlled (Bowman et al., 2011).

Thus, the results suggest that Ancylostomatidae eggs are more frequently found in feces, which makes more difficult the cutaneous larva migrans, given that feces are visible and people usually avoid to contact with them. However, the results also suggest that the soils from licensed areas are more frequently contaminated with Toxocara eggs, favoring the presence of visceral, ocular, and neurologic larva migrans-related diseases. Likewise, the results suggest that finding eggs must be interpreted differently based on parasite species and the substrate to be analyzed. For instance, if the same frequency of Ancylostomatidae and Toxocara eggs are found in soil samples, it is likely that Ancylostomatidae are more likely to be present in feces. The presence of parasitized dogs seems to be a more important factor when compared with the frequency with which the ground is cleaned of feces, given that licensed areas are more likely to be contaminated by parasites. Therefore, parasite control strategies should aim to reduce the presence of free-roaming dogs and to promote deworming practices.

\section{Acknowledgements}

English-language editing of this manuscript was provided by Journal Prep Services.

\section{References}

Acosta-Jamett G, Weitzel T, Boufana B, Adones C, Bahamonde A, Abarca K, et al. Prevalence and risk factors for echinococcal infection in a rural area of Northern Chile: a household-based cross-sectional study. PLoS Negl Trop Dis 2014; 8(8): e3090. http:// dx.doi.org/10.1371/journal.pntd.0003090. PMid:25167140.

Basso WU, Venturini L, Risso MA. Comparación de técnicas parasitológicas para el examen de heces de perro. Parasitol Día 1998; 22(1-2): 52-56. http://dx.doi.org/10.4067/S0716-07201998000100011.

Bowman DD, Eberhard ML, Lightowlers MW, Little SE, Lynn RC. Georgis' parasitología para veterinarios. Barcelona, España: Elsevier; 2011.

Collender PA, Kirby AE, Addiss DG, Freeman MC, Remais JV. Methods for quantification of soil-transmitted helminths in environmental media: current techniques and recent advances. Trends Parasito/ 2015; 31(12): 625-639. http://dx.doi.org/10.1016/j. pt.2015.08.007. PMid:26440788.

Ferreira JIGS, Pena HFJ, Azevedo SS, Labruna MB, Gennari SM. Occurrences of gastrointestinal parasites in fecal samples from domestic dogs in São Paulo, SP, Brazil. Rev Bras Parasito/ Vet 2016; 25(4): 435-440. http://dx.doi.org/10.1590/s1984-29612016081. PMid:27925072.

Giudice P, Hakimi S, Vandenbos F, Magana C, Hubiche T. Autochthonous cutaneous larva migrans in France and Europe. Acta Derm Venereol 2019; 99(9): 805-808. http://dx.doi.org/10.2340/00015555-3217. PMid:31073620.

Iannacone J, Alvariño Flores L, Cárdenas-Callirgos J. Contaminación de los suelos con huevos de Toxocara canis en parques públicos de Santiago de Surco, Lima, Perú, 2007-2008. Neotrop Helminthol 2012; 6(1): 97-108.

Medina-Pinto RA, Rodríguez-Vivas RI, Bolio-González ME. Nematodos intestinales de perros em parques públicos de Yucatán, México. Biomedica 2018; 38(1): 105-110. http://dx.doi.org/10.7705/biomedica.v38i0.3595. PMid:29668139.

Melín-Coloma M, Villaguala-Pacheco C, Lisboa-Navarro R, Landaeta-Aqueveque C. Estudio de la presencia de huevos de Toxocara sp. en suelos de áreas públicas de la ciudad de Chillán, Chile. Rev Chil Infectol 2016; 33(4): 428-432.

Mohd-Shaharuddin N, Lim YAL, Hassan NA, Nathan S, Ngui R. Molecular characterization of Trichuris species isolated from humans, dogs and cats in a rural community in Peninsular Malaysia. Acta Trop 2019; 190: 269-272. http://dx.doi.org/10.1016/j. actatropica.2018.11.026. PMid:30500371.

Quilodrán-González D, Gadicke P, Junod T, Villaguala-Pacheco C, Landaeta-Aqueveque C. Factores de riesgo asociados con parásitos gastrointestinales zoonóticos en perros de cabrero, región del Biobío, Chile. Chil J Agric Anim Sci 2018; 34(2): 118-125. http://dx.doi.org/10.4067/S0719-38902018005000401. 
Reyes R, Yohannessen K, Ayala S, Canals M. Estimaciones de la distribución del riesgo relativo de mortalidad por las principales zoonosis en Chile: enfermedad de Chagas, Hidatidosis, Síndrome cardiopulmonar por Hantavirus y Leptospirosis. Rev Chil Infectol 2019; 36(5): 599-606.

Rostami A, Ma G, Wang T, Koehler AV, Hofmann A, Chang BCH, et al. Human toxocariasis - a look at a neglected disease through an epidemiological ‘prism'. Infect Genet Evo/ 2019; 74: 104002. http://dx.doi.org/10.1016/j.meegid.2019.104002. PMid:31412276.

Ruiz de Ybáñez MR, Garijo M, Goyena M, Alonso FD. Improved methods for recovering eggs of Toxocara canis from soil.J Helminthol 2000; 74(4): 349-353. http://dx.doi.org/10.1017/S0022149X00000512. PMid:11138025.

Sievers G, Concha C, Gädicke P. Prueba de una técnica para recuperar huevos de Toxocara canis de muestras de tierra. Parasitol Latinoam 2007; 62(1-2): 61-66. http://dx.doi.org/10.4067/S0717-77122007000100010.

Sprenger LK, Green KT, Molento MB. Geohelminth contamination of public areas and epidemiological risk factors in Curitiba, Brazil. Rev Bras Parasitol Vet 2014; 23(1): 69-73. http://dx.doi.org/10.1590/S1984-29612014009. PMid:24728363.

Tamponi C, Varcasia A, Pinna S, Melis E, Melosu V, Zidda A, et al. Endoparasites detected in faecal samples from dogs and cats referred for routine clinical visit in Sardinia, Italy. Vet Parasitol Reg Stud Rep 2017; 10: 13-17. http://dx.doi.org/10.1016/j. vprsr.2017.07.001. PMid:31014584.

Traversa D. Are we paying too much attention to cardio-pulmonary nematodes and neglecting old-fashioned worms like Trichuris vulpis? Parasit Vectors 2011; 4(1): 32. http://dx.doi.org/10.1186/1756-3305-4-32. PMid:21385441.

Utaaker KS, Tysnes KR, Krosness MM, Robertson LJ. Not just a walk in the park: occurrence of intestinal parasites in dogs roaming recreational parks in Chandigarh, Northern India. Vet Parasitol Reg Stud Reports 2018; 14: 176-180. http://dx.doi.org/10.1016/j. vprsr.2018.10.008. PMid:31014725.

Vallejo A, Muniesa A, Ferreira C, Blas I. New method to estimate the sample size for calculation of a proportion assuming binomial distribution. Res Vet Sci 2013; 95(2): 405-409. http://dx.doi.org/10.1016/j.rvsc.2013.04.005. PMid:23623739.

White MAF, Whiley H, Ross KE. A review of Strongyloides spp. environmental sources worldwide. Pathogens 2019; 8(3): 91. http:// dx.doi.org/10.3390/pathogens8030091. PMid:31252665.

Zenner L, Gounel JM, Chauve CM. A standardized method for detecting parasite eggs and oocysts in soils. Rev Med Vet 2002; 153(11): 729-734. 